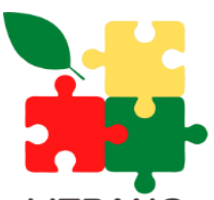

LITBANG

Edusaintech

\section{Jurnal Litbang Edusaintech (JLE)}

http://journal.pwmjateng.com/index.php/jle

\title{
Karakterisasi dan Identifikasi Orthetrum sabina (Odonata: Lebullidae) di Lapangan Rusunawa Jerakah Purwoyoso Semarang \\ Mubammad A'tourrobman ${ }^{1 *}$, Malia Ulfab ${ }^{1}$, Melin Septiani ${ }^{1}$, Fina Idamatus Silmi ${ }^{1}$, Ria Tri Utami ${ }^{1}$, Siti Faza Malianimah ${ }^{1}$, Sinta Dewi Rahmawati ${ }^{1}$ Afrizal Dwi Ananto ${ }^{\prime}$, Bita Afriyati Dewi ${ }^{2}$, Siti Mukblisoh Setyawati ${ }^{2}$
}

${ }^{1}$ Department of Biology, Faculty of Science and Technology UIN Walisongo, Semarang 50185, Indonesia ${ }^{2}$ Department of Biology Education, Faculty of Science and Technology UIN Walisongo, Semarang 50185, Indonesia

* Correspondence: E-mail: athoqsara11@gmail.com

\begin{abstract}
A B S T R A C T S
Dragonfly or odonata is one of the biodiversity in Indonesia. Dragonfly act as bioindicator of aquatic ecosystem and predator for mosquitoes. Dragonfly habitat is usually in a watery place such as a river. This study purpose to identify and characteristic dragonflies in the Rusunawa field. The type of research used is qualitative descriptive research, which aims to determine the morphology of dragonflies with Orthetrum sabina type and to know the environmental factors that affect dragonfly breeding. The method used in this study is roaming, by searching for dragonflies in the Rusunawa field Jerakah. The dragonfly population found in the Jerakah field is mostly one of which is Orthetrum sabina which has a dark green thoracic characteristic with black lines on the lateral side and black legs. The abdomen is slim in black and white, the embellant is white and has transparent wings. The number of dragonflies is influenced by several factors, namely temperature, climate, air humidity, water ph and insecticide use.
\end{abstract}

\author{
A R T I C L E I N FO \\ Article History: \\ Received 10 Oct 2020 \\ Revised 10 Nov 2020 \\ Accepted 10 Dec 2020 \\ Available online 15 Dec 2020
}

\section{Keyword:}

Odonata,

Identification,

Rusunawa Field,

\begin{abstract}
A B S T R A K
Capung atau odonata merupakan salah satu bidiversitas yang melimpah di Indonesia. Capung berperan sebagai bioindikator ekosistem perairan dan predator bagi nyamuk. Habitat capung biasanya di tempat yang berair seperti sungai. Penelitian ini bertujuan untuk mengidentifikasi dan mengkarakterisasi capung di lapangan Rusunawa Jerakah. Jenis penelitian yang digunakan adalah Penelitian kualitatif deskriptif, yang bertujuan untuk mengetahui morfologi capung dengan jenis Orthetrum sabina dan mengetahui faktor lingkungan yang mempengaruhi perkembangbiakan capung. Metode yang digunakan pada penelitian ini adalah jelajah, dengan mencari capung di lapangan Rusunawa Jerakah. Populasi capung yang ditemukan di lapangan jerakah banyak salah satunya yaitu Orthetrum sabina yang memiliki ciri toraks berwarna hijau tua dengan garisgaris hitam pada bagian lateral dan kaki berwarna hitam. Abdomen ramping dengan warna hitam dan putih, embelan berwarna putih serta memiliki sayap yang transparan. Jumlah capung dipengaruhi oleh beberapa factor yaitu suhu, iklim, kelembapan udara, $\mathrm{Ph}$ air dan penggunaan insektisida.
\end{abstract}

Keyword:
Odonata,
Identifikasi,
Lapangan Rusunawa Jerakah,




\section{INTRODUCTION}

Indonesia dikenal sebagai negara tropis dengan keanekaragaman hayati yang tinggi (Megabiodiversity) di dunia. Kondisi geografis Indonesia yang berpulau-pulau dan merupakan pertemuan kawasan biogeografi antara Oriental dan Australasia menjadikan Indonesia melimpah akan keanekaragaman spesies flora dan fauna. Salah satu fauna yang melimpah adalah fauna jenis Insecta (serangga). Menurut Bappenas (1993) ada 250.000 jenis serangga yang tersebar di wilayah Indonesia. Diantara kelompok serangga tersebut, salah satu serangga yang beragam berasal dari ordo Odonata.

Odonata merupakan salah kelompok serangga yang cukup dikenal karena memiliki warna mencolok dan menarik serta aktivitas diurnalnya sehingga cukup mudah diamati. Odonata berukuran sedang sampai besar dan tubuh odonata terdiri dari kepala (cephal), dada (toraks), perut (abdomen) yang langsing dan panjang, memiliki enam tungkai. Serangga ini menggunakan sebagian besar hidupnya untuk terbang.

Hampir 5.700 spesies Odonata dikenal di dunia saat ini. Beberapa spesies tersebar luas, sementara yang lain terbatas pada habitat yang sangat spesifik. Hingga saat ini belum bisa dipastikan berapa jumlah Odonata di Indonesia. Riset yang dilakukan oleh Indonesia Dragonfly Society (IDS) masih belum bisa memastikan berapa jumlah dari jenis Odonata di Indonesia, diperkirakan ada 700 jenis di Indonesia. (Sigit et al., 2013)

Capung memiliki kemiripan habitat berkembang biak dengan Aedes aegypti yaitu pada daerah yang berair. Capung mencari mangsa pada siang hari dengan makanannya berupa serangga kecil seperti nyamuk. Odonata merupakan kelompok serangga yang berukuran sedang sampai besar dan seringkali berwarna menarik. Serangga ini menggunakan sebagian besar hidupnya untuk terbang. Memiliki dua pasang sayap, berpembuluh darah yang tersusun seperti jala, antena pendek berbentuk rambut, alat mulut tipe pengunyah dan mata majemuk yang besar. Hidup di dua habitat yaitu pada saat pradewasa dalam air dan saat dewasa berada di dekat air. Sebagian besar spesies ditemukan di dekat air atau kolam, sungai, rawa-rawa dan di padang rumput, hutan dan perbukitan (Gesriantuti, 2018)

Odonata berperan sebagai bioindikator lingkungan yaitu indikator air (Gesriantuti, 2018). Selain itu, capung juga merupakan salah satu predator nyamuk, mulai dari tahap nimfa maupun serangga dewasa. Nimfa capung memakan larva nyamuk, demikian juga dengan capung dewasa memakan nyamuk dewasa (Syarifah, 2018).

Lapangan Jerakah merupakan ekosistem yang memiliki banyak vegetasi, selain itu juga bersebelahan dengan ekosistem sawah yang memiliki aliran air atau genangan air yang cocok untuk kehidupan capung. Penelitian mengenai keanekaragaman Odonata telah banyak dilakukan antara lain oleh Gesriantuti (2018), ditemukan 15 spesies capung di Stadion Utama Riau, Syarifah (2018) menemukan 5 spesies di TMII, Muktitama (2018) menemukan 13 jenis Anisoptera dan 3 jenis Zygoptera. Penelitian ini bertujuan untuk mengidentifikasi dan mengkarakterisasi lebih spesifik kepada satu spesies yaitu Ortethrum Sabina dan mempelajari daur hidup serta faktor yang mempengaruhi perkembangbiakannya.

\section{METHODS}

Penelitian ini dilakukan pada bulan Desember 2018 di lapangan Rusunawa Jerakah Tugu Kota Semarang. Sampel capung diidentifikasi di Laboratorium Biologi Fakultas Sains dan Teknologi Universitas Islam Negeri Walisongo Semarang.

Alat dan bahan yang digunakan dalam penelitian ini diantaranya yaitu jaring insecnet yang digunakan untuk menangkap serangga, jarum suntikan, alat untuk mengukur suhu dan kelembabpan (termohigrometer), alat untuk mengukur intensitas cahaya (lux meter), alat pengukur $\mathrm{pH}$ ( $\mathrm{pH}$ sticik), Kamera hp untuk dokumentasi, amplop untuk menyimpan capung, alkohol 70\%.

Pengambilan data dilakukan dengan menggunakan metode jelajah (field by field) pada 
lokasi yang telah ditentukan dan pendataan jenis dilakukan dengan pengumpulan capung yang dijumpai dan diidentifikasi di laboratoriuom biologi (Gesriantuti, 2018). Identifikasi jenis capung dilakukan dengan memperhatikan warna, bentuk tubuh, bentuk dan posisi sayap, mata serta perilaku terbang. Identifikasi dilakukan dengan menggunakan aplikasi Odonataku dan juga buku panduan tentang serangga LIPI. Pendataan faktor lingkungan juga dilakukan pada lokasi penelitian. Faktor lingkungan yang dicatat antara lain suhu, kelembaban udara, intensitas cahaya, pH air.

\section{RESULTS AND DISCUSSION}

\section{Morfologi Orthetrum sabina}

Orthetrum sabina adalah jenis capung yang ditemukan di lapangan Jerakah. Othetrum sabina ini memiliki panjang abdomen $35 \mathrm{~mm}$ dengan panjang torax $13 \mathrm{~mm}$, panjang sayap depan dan belakang masing-masing $33 \mathrm{~mm}$ dan $32 \mathrm{~mm}$ dengan lebar sayap depan dan belakang masing-masing $8 \mathrm{~mm}$ dan $10 \mathrm{~mm}$. Torax yang dimiliki capung ini berwarna hijau tua dengan garis-garis hitam pada bagian lateral dan kakinya berwarna hitam. Abdomen ramping dengan warna hitam dan putih, segmen pertama hingga ketiga berwarna sama dengan toraxnya. Sedangkan embelan berwarna putih, sayap yang dimiliki orthetrum sabina adalah transparan dengan disetiap ujung sayap terdapat pteristigma yang berwarna coklat dengan fenula tidak berwarna.

Pada bagian kepala terdapat, mata, mulut, dan gigi. Dengan matanya menyatu digaris tengah. Mulutnya berkembang sesuai dengan fungsinya sebagai pemangsa, bagian depan terdapat labrum (bibir depan), di belakang labrum terdapat sepasang mandibula (rahang) yang kuat untuk merobek mangsanya. Kemudian di belakang mandibula terdapat sepasang maxilla yang berguna untuk membantu pekerjaan mandibula, dan bagian mulut yang paling belakang adalah labium yang menjadi bibir belakang.

\section{Daur Hidup Orthetrum sabina}

Daur hidupnya, capung melalui tiga tahap perubahan bentuk (metamorphosis), yaitu telur, nimfa, dan dewasa. Perubahan bentuk seperti ini dinamakan metamorfosis tidak sempurna (Hemimetabola). Ketika baru menetas nimfa terlindungi oleh selaput tipis, tingkatan ini disebut pronimfa. Setelah bersentuhan dengan air selaput tipis terbelah dan muncul nimfa instral. Dalam perkembangan nimfa capung mengalami pergantian kulit, tergantung jenis dan adaptasinya dengan lingkungan. Pergantian kulit berkisr antara 6-15 kali (Miller, 1995).

Proses pergantian kulit atau (ecdysis) diawali dengan gerakan memompa mengalirkan cairan tubuh menuju torax dan menyebabkan torax mengembung dan akhirnya terjadi sobekan pada permukaan dorsal yang meluas sampai di belakang mata dan terbentuk gambaran menyerupai huruf Y. Melalui sobekan tersebut secara spontan nimfa terdorong keluar.

Capung yang baru muncul berwarna pucat, lunak dan sayap mengkilat. Pada waktu terbang pertama memisahkan diri dari air dan memerlukan waktu beberapa hari untuk mencari makanan. Saat itu capung mengembangkan warna yang sebenarnya dan secara seksual menjadi masak. Jika masa kematangannya sudah selesai lalu mencari lingkungan air untuk masa pembiakan.

\section{Faktor yang mempengaruhi perkembangbiakan}

Populasi capung juga dipengaruhi oleh faktor abiotik dalam perkembangan hidupnya, seperti penggunaan insektisida. Insektisida yang digunakan secara tidak langsung dapat berdampak pada populasi capung. Hal ini telah dinyatakan oleh Qayyimah et al. (2014) bahwa capung ordo odonata merupakan salah satu insecta yang mengalami kerugian hebat akibat penggunaan insektisida. Namun, pada pengamatan yang dilakukan di lapangan Rusunawa Jerakah menunjukkan populasi capung terlihat masih melimpah.

Populasi capung juga dapat dipengaruhi oleh musim, seperti pada musim penghujan populasi capung akan melimpah dibanding musim kemarau, hal itu menunjukkan bahwa suhu juga mempengaruhi populasi capung. Saat pengamatan suhu di lapangan Rusunawa Jerakah $30,80^{\circ} \mathrm{C}$ dan kelembapan udara adalah 
$76 \%$. Kedua parameter tersebut memiliki korelasi positif atas keanekaragaman dan kelimpahan capung, karena Temperatur dan kelempaban lingkungan merupakan salah satu faktor yang mempengaruhi aktivitas capung (Hermawan, 2015). pH air juga mempengaruhi populasi capung, $\mathrm{pH}$ air yang cocok untuk kelangsungan hidup capung adalah netral. Hal ini juga terlihat dari $\mathrm{pH}$ air di area swah sekitar Rusunawa Jerakah menunjukkan pH 7.

\section{CONCLUSION}

Orthetrum sabina adalah jenis capung yang ditemukan di lapangan Rusunawa Jerakah. Torax yang dimiliki capung ini berwarna hijau tua dengan garis-garis hitam pada bagian lateral dan kakinya berwarna hitam. Abdomen ramping dengan warna hitam dan putih. Daur hidup, capung melalui tiga tahap perubahan bentuk (metamorphosis), yaitu telur, nimfa, dan dewasa. Perubahan bentuk seperti ini dinamakan Metamorfosis tidak sempurna (Hemimetabola). Ketika baru menetas nimfa terlindungi oleh selaput tipis, tingkatan ini disebut pronimfa. Dalam perkembangan nimfa capung mengalami pergantian kulit, tergantung jenis dan adaptasinya dengan lingkungan, pergantian kulit berkisar antara 6-15 kali. Populasi capung dipengaruhi oleh beberapa faktor, diantaranya keberadaan serangga, musim, suhu, kelembapan udara dan $\mathrm{pH}$ air.

\section{REFERENCES}

Gesriantuti, N., Herlina, N., \& Yunita, N. (2018). Jenis-Jenis Odonata Di Kawasan Stadion Utama Riau, Pekanbaru. Jurnal Photon, 9(1), 197-202.

Hermawan, Adi Septianto dan Fitriana, Narti. (2015). Jenis dan fluktuasi capung pada Taman Kota Bumi Serpong Damai, Tangerang Selatan, Banten. Jurnal PROS SEM NAS MASY BIODIV INDO, 1(8), 1795-1801.

Irawan, F., Hadi, M., \& Tarwotjo, U. (2017). Struktur Komunitas Odonata di Kawasan Wana Wisata Curug Semirang Kecamatan Ungaran Barat, Semarang. Bioma: Berkala Ilmiah Biologi, 19(1), 69-75.
Muktitama, S. R., Prayogo, H., \& Indrayani, Y. Keanekaragaman Jenis Capung Di Kawasan Kampus Universitas Tanjungpura Pontianak. Jurnal Hutan Lestari, 6(4).

Patty, Novita. (2006). Keanekaragaman Jenis Capung (Odonata) Di Situ Gintung Ciputat, Tangerang. Skripsi UIN Syarif Hidayatullah

Rizal, Samsul dan hadi, Muhammad. 2015. Inventarisasi Jenis Capung (Odonata) Pada Areal Persawahan Di Desa Pundenarung Kecamatan Karang Awen Kabupaten Demak. Jurnal bioma. Vol. 17(1). 16-20.

Sigit, W., Feriwibisono, B., Nugrahani, P. M., Putri, B., dan Makitan, T. 2013. Naga Terbang Wendit. Keanekaragaman Capung Perairan Wendit, Malang Jawa Timur. Indonesia Dragonfly Society. Jawa Timur.

Syarifah, E. B., Fitriana, N., \& Wijayanti, F. (2018). Keanekaragaman Capung (Odonata) Di Taman Mini Indonesia Indah Dan Taman Margasatwa Ragunan, Dki Jakarta, Indonesia. Bioprospek: Jurnal Ilmiah Biologi, 13(1), 50-58.

Qayyimah, F. D., Lulu'Nisrina, R. A., \& Rosnaeni, Y. B. (2014). "Odonata Diversity Relationship with Plant Vegetation Diversity in Palimanan Quarry, Cirebon, West Java. Final Report University Al-Azhar of Indonesia. 